the nest are given. R. O. Noone describes caves and some cave formations, and submits eight photographs of unusual interest, especially one of strange calcite growths which are even now not satisfactorily explained. The president, E. O. Shebbeare, gives a short but interesting account of an elephant trek. In a paper on Malayan bears, A. H. Fetherstonhaugh describes chiefly two bears in captivity. The illustrations of these are particularly fascinating. A few observations are also made on bears in their native jungles. G. S. Ogilvie presents a descriptive account of the 'Che Wong', a little-known primitive tribe from an area well known for its diversity of primitive peoples. This account is also supported by well-produced photographs. The Journal has certainly made a good start, and we wish it success and much support. The annual subscription is six dollars (single numbers, two dollars). A few spare copies of the first number are available at Malaya House (Mr. G. E. Cator), 57 Trafalgar Square, London, W.C.2.

\section{Dried Onions}

THE trade in dried onions developed after the War of 1914-18, and there is now a big demand for this material on the Continent (Bull. Imp. Inst., 38, No. $3 ; 1940$ ). In Great Britain the quantity used in 1939 was only about 400 tons, but in view of the scarcity of the fresh vegetable an increase may be expected. Hitherto, supplies to Great Britain have come from southern Europe; but as these are no longer available it is suggested that Empire sources be developed. The method of preparing the onions is briefly as follows: The bulbs are peeled by hand and cut into thin slices which may then be immersed in a 5 per cent salt solution for 3-5 minutes to prevent discoloration. Drying is carried out on trays in tunnel driers for about 5-10 hours, the slices being kept turned to hasten the process. The temperature should not be allowed to rise above $140^{\circ} \mathrm{F}$., or flavour is lost and the slices darken.

The finished material should be dry and crisp with a moisture content of 5-7 per cent. Sun drying is said to give less satisfactory results than artificial drying. The dried product is usually shipped in tinlined cases of 1 or 2 cwt. each, the material fetching between 65-70 shillings per cwt. before the War, but by August 1940 it was worth 150 shillings per cwt. in London. On an average, one ton of the dried material represents about 10 tons of fresh onions. The Imperial Institute, London, would be glad to receive samples of dried onions from Empire sources with the view of submitting them to the trade for a report on their market possibilities.

\section{Mineral Products of the British Empire and U.S.A}

THE possibility of a joint control of essential minerals and other natural products by the United States and the British Empire as a means of preventing future wars or of curtailing their duration is raised again by Dr. William Cullen in a paper contributed to Chemistry and Industry of November 30. Dr. Cullen suggests that the great distance which public opinion in the United States and elsewhere has travelled in the past few months brings a mineral sanction within the bounds of possibility. He points out that apart from food the two most essential materials in modern warfare are steel and oil. Good steel cannot be made without manganese, and in all Europe there is no appreciable amount of manganese. Even with Poland and Rumania, Europe is very badly off for mineral oil. The United States of America and the British Commonwealth control 75 per cent of the world's reserves of economic minerals, and if the United States and the British agreed by treaty that no aggressor nation should be supplied with essential metals and minerals, and that during peace, steps should be taken to prevent the accumulation of reserves by any other nation, it would be impossible for any aggressors to carry on a war for any lengthened period. With the pronounced change in American opinion, Sir Thomas Holland may see the fruition of all his labours in this field.

\section{New World Populations and the Future}

IN another column of this issue of NATURE (see p. 783), certain figures are extracted from a comparative study by Prof. Raymond Pearl of the populations of the New World and the Old. After making allowance for any inaccuracies and uncertainties in the data upon which his study is based, he arrives at the conclusion that, when they are examined in respect of certain criteria, such as density of population in a given unit of space, rate of growth, age distribution and the like, the populations of the New World, as contrasted with those of the Old, have in a biological sense all the characteristics of a young and vigorous organism, and that this fact carries with it certain social and psychological implications. Thus he points out that the relatively low figure for the density of population implies freedom of movement and expansion in settlement, the vigour indicated by the rate of increase of population and a higher birth-rate affords freer play for the forces of natural selection and the production of a virile and healthy stock, while the higher proportion of the population of pre-reproductive age holds out promise of a bold and enterprising outlook as against the pessimistic and despondent attitude of mind in a community such as that of the Old World, in which no less than one fifth of the whole has passed the active age of production.

Taken on the basis of an abstraction, Prof. Pearl's analysis is impressive; but it has the weakness of all abstractions that it presents only a certain aspect, or certain aspects of reality. This he admits when he feels constrained to pass by the criterion of 'quality', on the ground that it is difficult or impossible to apply with scientific accuracy. He finds that quality, however, as the eugenist would maintain, does open the way in one direction at least in which Old World populations may seek to redress the balance against them. Prof. Pearl himself, indeed, directs attention to certain dangers in the future of the post-War world to which his figures point as arising out of the very advantages which America enjoys. While, 